\title{
PERILAKU SOSIAL ATLET PUTERI CABANG OLAHRAGA FUTSAL
}

\author{
(Studi Ex-Post Facto Pada UKM Futsal Puteri UPI Bandung)
}

Ani Kurniawati
Program Studi Olahraga Sekolah Parscasarjana Universitas Pendidikan Indonesia

Jl. Setiabudi No. 229 Bandung, Jawa Barat 40154

Email: a.k_thasaa@yahoo.co.id

\begin{abstract}
Abstrak
Tujuan penelitian adalah untuk mengetahui gambaran perilaku sosial atlet puteri cabang olahraga futsal. Metode yang digunakan ex-post facto. Populasi dan sampel penelitian adalah seluruh mahasiswa yang mengikuti UKM Futsal Puteri UPI Bandung sebanyak 26 orang. Instrument yang digunakan adalah test perilaku sosial dalam bentuk angket yang diambil dari Willis (2012). Pengolahan dan analisis data pada penelitian dengan menggunakan persentase. Hasil pengolahan dan analisis data dari keseluruhan perilaku sosial atlet puteri cabang olahraga futsal pada mahasiswa yang mengikuti UKM futsal puteri UPI Bandung sebesar 65\%, yaitu baik dan dominan memiliki perilaku sosial dalam penyesuaian diri terhadap diri sendiri sebesar $85.2 \%$, yaitu sangat baik. Sedangkan dari butir-butir pernyataan tiap sub komponen yang paling menonjol adalah adanya keinginan yang besar, sedangkan kemampuan yang dimiliki kurang sebesar 92.2\%, yaitu sangat baik. Kesimpulan, dari hasil penelitian ini dapat disimpulkan bahwa perilaku sosial atlet puteri cabang olahraga futsal pada mahasiswa yang mengikuti UKM Futsal Puteri UPI Bandung memiliki perilaku sosial yang baik.
\end{abstract}

Kata kunci : Perilaku sosial, olahraga futsal. 


\section{PENDAHULUAN}

Olahraga hingga kini kian meluas dan memiliki makna sebagai sebuah fenomena yang bersifat global, mencakup wilayah kajian hampir seluruh sendi-sendi kehidupan manusia. Menyentuh dan disentuh bidang-bidang lain seperti: pendidikan, ekonomi, politik, sosial budaya, psikologi, sosiologi, fisiologi dll. Luasnya wilayah kajian olahraga adalah pangkal yang menggiring banyak pihak memberikan pandangan yang berlainan tentang olahraga. Namun demikian, yang terpenting adalah olahraga dipandang sebagai perilaku gerak manusia yang bersifat universal. Perilaku gerak yang tidak hanya berorientasi pada tujuan fisik semata, namun juga aspek jiwa. Seperti yang dikemukakan Osterhound 1973 (2010:2) menjelaskan bahwa: “Olahraga sebagai perilaku gerak manusia adalah media untuk mengekspresikan body and mind secara harmonis". Sedangkan definisi olahraga yang dikemukakan oleh Matveyey 1981 (2001:37) menjelaskan bahwa: "Olahraga merupakan kegiatan otot yang energik dan dalam kegiatan itu atlet memperagakan kemampuan geraknya (performa) dan kemauannya semaksimal mungkin". Mengacu pada pendapat tersebut dapat disimpulkan bahwa olahraga sebagai aktivitas fisik yang pada hakekatnya tidak terlepas dari aspek-aspek jiwa yang dapat mempengaruhi dan menjadi dasar seseorang dalam melakukan kegiatannya.

Olahraga merupakan sebuah fenomena sosial-budaya yang perlu untuk dipahami dan dipelajari. Hal ini dikarenakan olahraga secara budaya telah melekat kuat dalam diri individu dan masyarakat. Coakley (2001:2) menjelaskan bahwa: "Sports are more than just games and meets, they are also social phenomena that have meanings that go far beyond scores and performance statistic". Olahraga bukan hanya sekedar permainan dan pertandingan, tetapi juga merupakan sebuah fenomena sosial yang memiliki makna lebih jauh dari sekedar angka dan statistik penampilan. Olahraga futsal kini sudah menjadi olahraga permainan yang diminati dari berbagai kalangan, hal ini dikarenakan permainan futsal dapat dilakukan oleh siapa saja, mulai dari anak-anak sampai orang dewasa, baik lakilaki maupun perempuan. Olahraga futsal merupakan modifikasi dari permainan sepak bola. 
Modifikasi ini berupa pengurangan pada ukuran lapang, bentuk dan ukuran peralatan yang digunakan, jumlah pemain dan aturan permainan. Dalam hal ini, permainan futsal merupakan olahraga beregu yang dimainkan oleh dua regu, setiap regu terdiri dari lima orang pemain termasuk penjaga gawang. Olahraga futsal merupakan bagian dari olahraga sepak bola. Seperti yang diungkapkan oleh Micheli dan Jenkins 2001 (2012:165) menjelaskan bahwa: "Sepak bola wanita merupakan satu dari cabang olahraga yang berkembang menonjol". Hal ini terbukti bahwa pengetahuan mengenai olahraga pada pria berbeda dengan wanita. Dalam hal ini, olahraga yang menonjol itu adalah olahraga futsal.

Perkembangan olahraga wanita, dalam hal ini adalah perkembangan olahraga futsal puteri di Jawa Barat, khususnya di daerah Bandung saat ini sudah mengalami banyak perubahan. Hampir di setiap daerah di Bandung mulai dari kota sampai kabupaten memiliki banyak tempat latihan futsal yang memadai. Oleh karena itu, pada tahun 2014 terjadi peningkatan jumlah pertandingan, mulai dari tataran persekolahan, perguruan tinggi dan masyarakat secara umum. Dampak dari peningkatan jumlah kompetisi tersebut bertujuan pada peningkatan jumlah atlet, hal ini diindikasikan dengan lahirnya klub cabor permainan futsal yang diminati bukan hanya oleh kaum laki-laki saja, tetapi seiring berjalannya waktu minat pada olahraga futsal ini juga menarik perhatian kaum wanita.

Olahraga beregu (team sport) merupakan salah satu bentuk olahraga yang dapat mengembangkan keterampilan sosial seseorang. Hal ini dikarenakan olahraga beregu akan membentuk sebuah situasi sosial yang dapat memberikan kesempatan kepada individu untuk berinteraksi dengan orang lain. Salah satu bagian dari keterampilan sosial adalah perilaku sosial. Perilaku sosial merupakan suasana saling ketergantungan yang memiliki keharusan untuk menjamin keberadaan manusia. Perilaku sosial juga identik dengan reaksi seseorang terhadap orang lain. Perilaku secara umum akan terbentuk dari beberapa komponen dasar, mengenai komponen pembentuk perilaku ada beberapa komponen yang menunjangnya, dalam hal ini Mar'at (1982:13) menjelaskan bahwa komponen perilaku sosial adalah sebagai berikut: “a) Komponen kognisi yang hubungannya dengan beliefs, ide 
dan konsep, b) Komponen afeksi yang menyangkut kehidupan emosional seseorang, c) Komponen konasi yang merupakan kecenderungan bertingkah laku". Oleh sebab itu, perilaku seseorang merupakan sifat relatif untuk menanggapi orang lain dengan cara-cara yang berbeda-beda. Misalnya dalam melakukan kerjasama, ada orang yang melakukannya dengan tekun, sabar dan selalu mementingkan kepentingan bersama di atas kepentingan pribadinya. Sementara di pihak lain, ada orang yang bermalas-malasan, tidak sabaran dan hanya ingin mencari untung sendiri.

Olahraga futsal merupakan salah satu bentuk dari olahraga sepak bola yang dapat memfasilitasi terjadinya interaksi sosial antar pemain dalam satu tim, pemain dengan tim lain, dan diantara kedua tim yang saling berlawanan. Setiap individu memiliki peran dan status sendiri dalam interaksi sosial, tetapi dalam satu kelompok terdapat ikatan berupa seperangkat hubungan sosial yang khusus. Interaksi sosial yang terjadi adalah dalam bentuk kompetisi, kerjasama, kompromi, dan konflik.

Seorang individu membutuhkan kemampuan untuk dapat berinteraksi dengan orang lain. Kemampuan itu adalah keterampilan sosial (social skill). Keterampilan sosial merupakan salah satu kemampuan yang dimiliki individu dalam menjalani hubungan dengan orang lain dan kemampuan memecahkan masalah, dengan keterampilan yang individu miliki suatu lingkungan sosial yang harmonis akan dicapai. Keterampilan sosial sangat berhubungan erat dengan interaksi sosial, itu terjadi karena interaksi sosial yang terjadi dalam suatu situasi sosial dapat mendeskripsikan keterampilan sosial seseorang dan keterampilan sosial juga memiliki peran dan kedudukan yang sangat penting bagi individu agar dapat hidup bermasyarakat di kemudian hari.

Di Universitas Pendidikan Indonesia (UPI) kegiatan ekstrakurikuler bagi mahasiswa dibentuk dan dikelola sendiri oleh mahasiswa dengan nama Unit Kegiatan Mahasiswa (UKM). Unit Kegiatan Mahasiswa (UKM) yang bergerak dalam bidang keolahragaan dibentuk dengan tujuan yaitu untuk meningkatkan dan menumbuhkan potensi, kemampuan, bakat, dan minat mahasiswa, khususnya dalam bidang olahraga agar 
terciptanya sehat jasmani dan rohani. Selain tujuan tersebut Unit Kegiatan Mahasiswa (UKM) keolahragaan di Universitas Pendidikan Indonesia (UPI) memiliki tujuan membina dan mengembangkan potensi mahasiswa khususnya prestasi dibidang keolahragaan. Hal ini dijelaskan dalam buku Menuju Keberhasilan Studi Mahasiswa (2007:42) adalah sebagai berikut: "Mahasiswa yang tergabung dalam Unit Kegiatan Mahasiswa (UKM) keolahragaan dapat memperdalam kemahiran sehingga dapat diarahkan untuk menjadi atlet universitas, daerah bahkan nasional". Sehingga dapat dilihat bahwa tujuan kegiatan ekstrakurikuler keolahragaan khususnya di perguruan tinggi dan di semua jenjang pendidikan formal pada umumnya tidak hanya untuk membantu mencapai tujuan pendidikan nasional saja, melainkan lebih luas yaitu membina dan meningkatkan potensi, kemampuan, minat, bakat, dan pestasi mahasiswa khususnya di bidang olahraga.

Kegiatan UKM juga dapat dimanfaatkan untuk mengajarkan nilai-nilai moral, seperti kejujuran dan fair play. Tugas penting yang perlu dilakukan oleh pelatih dan pembina adalah bagaimana merancang pengajaran atau pelatihan sehingga melibatkan nilai-nilai moral tertentu yang didiskusikan dalam satu situasi yang intens dan dapat mengundang keputusan moral yang perlu dilakukan. Demikian juga dengan dampak dari kegiatan UKM terhadap perilaku sosial. Pengembangan perilaku sosial melalui kegiatan UKM perlu dikembangkan melalui perencanaan pengajaran atau pelatihan yang seksama, konsisten dengan aplikasi dari sebuah kontingensi. Suatu kontingensi yang menghubungkan antara suatu perilaku sosial dengan konsekuensinya. Sebuah kontingensi adalah suatu alasan mengapa mahasiswa perlu menampilkan perilaku sosial yang diinginkan. Pelatih ataupun pembina UKM perlu menunjukan bukti alasan pada mahasiswa mengapa perilaku sosial itu perlu dilakukan melalui pemberian alasan-alasan kongkrit, seperti akan memungkinkan adanya gejala-gejala sosial baru bersifat negatif yang dapat dilakukan secara tidak disadari oleh mahasiswa itu sendiri. Berbagai masalah sosial itu tentunya tidak akan timbul apabila individu-individu dalam masyarakat memiliki perilaku sosial yang baik. 
Perubahan dari kegiatan mengikuti UKM keolahragaan ini jelas berpengaruh pada perilaku sosial. Seperti halnya Kusumawati (2010), dalam penelitiannya kegiatan ekstrakurikuler olahraga memberikan dampak lebih besar terhadap perilaku sosial terhadap siswa dibandingkan kegiatan ekstrakurikuler non olahraga, karena dengan mengikuti kegiatan ekstrakurikuler olahraga secara tidak sadar siswa akan dapat merubah perilaku sosial ke arah yang lebih positif dengan sendirinya yaitu melalui permainan dan olahraga. Sedangkan Nopembri (2008), dalam penelitiannya mengimplikasikan bahwa olahraga futsal harus dapat dikembangkan menjadi olahraga masyarakat yang disinergikan dengan olahraga pendidikan dan prestasi serta model pengembangan keterampilan sosial. Melalui olahraga futsal dapat diaplikasikan dalam pendidikan dengan merancang pembelajaran yang dapat menciptakan interaksi sosial yang positif untuk merangsang timbulnya berbagai perilaku positif yang mengarah pada pengembangan keterampilan sosial.

Keuntungan dari pelaksanaan kegiatan UKM dalam hal ini adalah UKM futsal itu sendiri adalah dapat merubah tatanan perilaku sosial sehingga bisa tercapainya aspekaspek perilaku sosial yang diinginkan seperti adanya kerjasama, kemurahan hati, persaingan positif, empati, sikap tidak mementingkan diri sendiri, sikap ramah, kepemimpinan yang dapat menunjang perkembangan keterampilan sosial mereka memasuki dunia setelah mereka berada di dunia masyarakat di kehidupan sosial.

Kesuksesan berawal dari sebuah mimpi, dan mimpi itu adalah ingin mengembangkan olahraga wanita, salah satunya adalah melalui olahraga futsal. Sebagaimana penulis jelaskan sebelumya, atlet puteri yang mengikuti cabor ini telah menjalani peningkatan dari sisi kuantitas dan kualitas. Oleh sebab itu, mengacu pada berbagai kajian baik secara anatomi fisiologi maupun sosial budaya, permainan futsal kerap dijadikan sebagai olahraga maskulin dan segala perubahan yang terjadi dalam kehidupan sosial kaum wanita itu tidak saja mempengaruhi secara langsung bahkan tidak juga mengubah kedudukan wanita dalam kehidupan sosial. Tetapi, perubahan tersebut pada 
akhirnya akan mempengaruhi kepribadian kaum wanita itu sendiri. Dalam hal ini Harsono (1998:44) menjelaskan bahwa: "Secara sederhana kepribadian seseorang biasanya dicerminkan oleh sifat-sifat, ciri-ciri, perangkai, kebiasaan-kebiasaannya yang khas yang membedakannya dengan kepribadian orang lain". Selain itu juga Harsono (1998:45) menjelaskan bahwa: "Berbagai faktor yang bisa menyebabkan perubahan-perubahan tersebut adalah faktor lingkungan, faktor-faktor fisik, mental, emosional, sosial, dan inteligasi". Oleh karena itu, perkembangan kepribadiaan selalu dinamis, tidak statis, sehingga tidak akan pernah berhenti dan perubahan-perubahan itu bisa saja terjadi selama hidupnya. Disamping itu juga sifat, perangkai, kebiasaan juga bisa saja mendominasi kepribadian kita pada usia muda, untuk kemudian hilang pada waktu kita dewasa.

Perilaku sosial yang terjadi dalam olahraga futsal diharapkan dapat menjadi wahana bagi individu untuk bisa mengembangkan keterampilan sosial dalam hal ini adalah perilaku sosial yang sangat dibutuhkan dalam kehidupan bermasyarakat. Berkaitan dengan permasalahan dalam penelitian ini, maka fokus telaahan berupaya untuk melihat data empirik berbagai bentuk perilaku sosial yang ada pada kelompok wanita yang menggeluti cabor futsal. Berdasarkan latar belakang di atas, dalam penelitian ini penulis tertarik untuk meneliti perilaku sosial yang terjadi dan mengetahui faktor-faktor apa yang menyebabkan adanya perilaku sosial itu. Dalam hal ini penulis juga lebih memfokuskan penelitian dalam mendeskripsikan gambaran perilaku sosial atlet puteri cabang olahraga futsal pada mahasiswa yang mengikuti UKM futsal puteri UPI Bandung.

\section{METODE}

Metode dalam penelitian ini adalah ex-post facto. Alasan penulis menggunakan metode ini adalah pada penelitian ini telah terjadi sebelum peneliti melakukannya. Peneliti tidak melakukan kontrol terhadap perlakuan tersebut. Dalam hal ini peneliti hanya mngambil data mengenai pengaruh variabel bebas terhadap variabel terikat yang diteliti.

Populasi dan sampel pada penelitian ini adalah seluruh mahasiswa yang mengikuti UKM Futsal Puteri UPI Bandung yang berjumlah 26 orang. Dalam penelitian ini, peneliti 
menggunakan teknik sampling jenuh sebagai teknik pengambilan sampelnya. Alasan pengambilan sampel ini dikarenakan jumlah sampel yang mengikuti kegiatan UKM Futsal Puteri sebanyak 26 orang.

Desain yang digunakan adalah desain hubungan simetris. Desain hubungan simetris terjadi jika dua variabel atau lebih berhubungan tetapi bukan dalam bentuk sebab akibat maupun timbal balik kognitif. Penelitian dilakukan pada hari Rabu yaitu dengan pengambilan data berupa angket perilaku sosial dan wawancara kepada pelatih dan atlet.

Instrumen adalah suatu alat yang digunakan untuk mengukur fenomena alam maupun sosial yang diamati. Dalam penelitian ini penulis mengembangkan komponen dalam pembuatan angket, Willis (2012:140) mengemukakan bahwa yang termasuk komponen dalam skala perilaku sosial terdapat empat sub skala yakni penyesuaian diri terhadap diri sendiri, penyesuaian diri di dalam keluarga, penyesuaian diri di sekolah (lembaga pendidikan), dan penyesuaian diri di masyarakat. Adapun alasan menggunakan angket ini adalah karena penyusuaian diri adalah kemampuan bereaksi secara efektif dan sehat terhadap situasi, realita, dan hubungan sosial sehingga tuntutan hidup bermasyarakat terpenuhi dengan cara yang dapat diterima dan memuaskan. Untuk lebih jelas lagi Willis (2011:140) menjelaskan bahwa: "Penyesuaian diri adalah kemampuan untuk hidup dan bergaul secara wajar terhadap lingkungannya, sehingga ia merasa puas terhadap dirinya sendiri dan terhadap lingkungannya.

\section{HASIL DAN PEMBAHASAN}

Langkah-langkah yang ditempuh dalam pengolahan dan analisis data adalah sebagai berikut:

Persentase gambaran perilaku sosial atlet puteri cabang olahraga futsal pada mahasiswa yang mengikuti UKM futsal puteri UPI Bandung dari setaip sub komponen dapat dilihat pada grafik 4.1 dibawah ini: 


\section{Gambar 4.1}

Persentase Sub Komponen Perilaku Sosial

\section{Persentase Sub Komponen Perilaku Sosial}

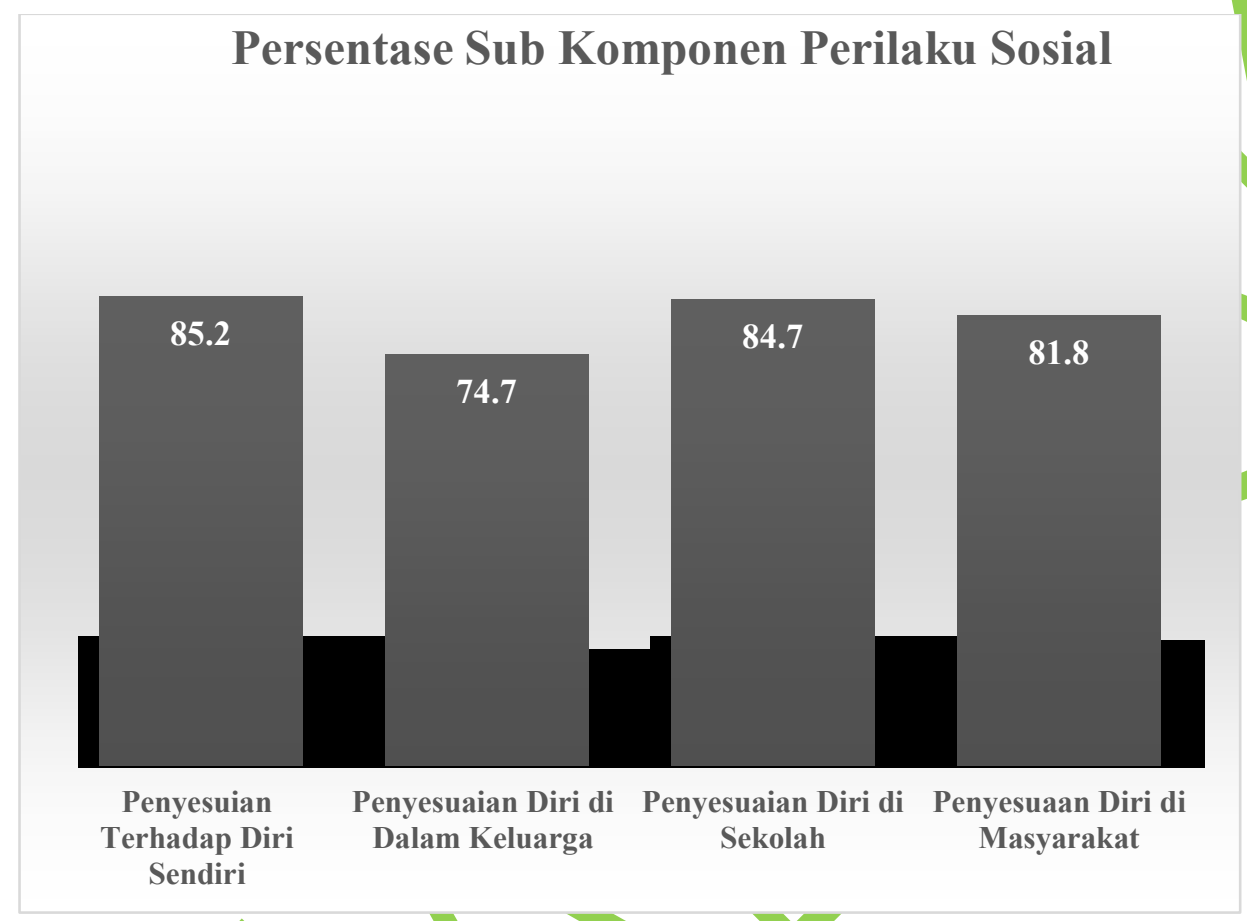

Kesimpulanya gambaran perilaku sosial atlet puteri cabang olahraga futsal pada mahasiswa puteri yang mengikuti UKM futsal puteri UPI Bandung dominan memiliki penyesuaian diri terhadap diri sendiri dengan persentase nilai sebesar $85.2 \%$, yaitu sangat baik.

Persentase gambaran perilaku sosial atlet puteri cabang olahraga futsal pada mahasiswa yang mengikuti UKM futsal puteri UPI Bandung dari setaip butir-butir tiap sub komponen dapat dilihat pada grafik 4.2 dibawah ini: 


\section{Gambar 4.2}

Persentase Butir-Butir Tiap Sub Komponen

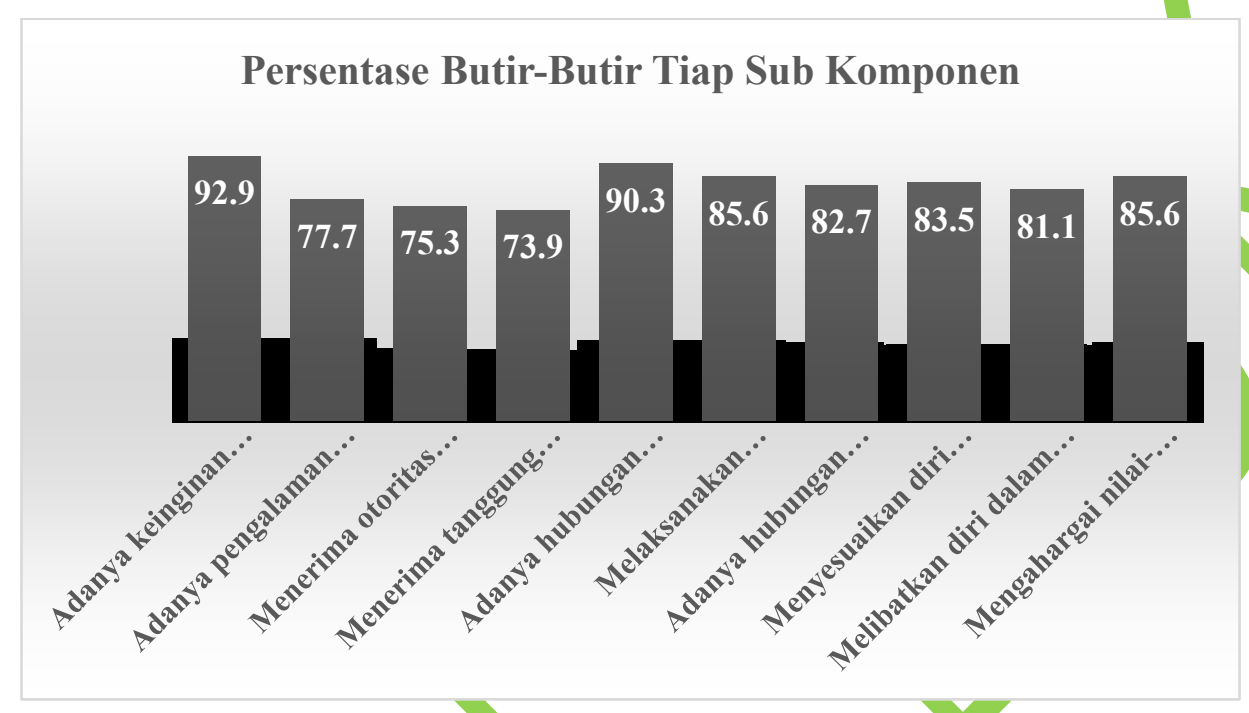

Kesimpulannya dilihat dari persentase di atas dapat disimpulkan bahwa dari butirbutir pernyataan tiap sub komponen yang paling menonjol adalah adanya keinginan yang besar, sedangkan kemampuan yang dimiliki kurang dengan persentase yang di dapat adalah $92.2 \%$, yaitu sangat baik.

\section{PEMBAHASAN}

Hasil penelitian yang dilakukan, penulis menemukan penemuan yang diuraikan pada bagian pembahasan ini. Mengenai perubahan perilaku sosial yang dimiliki mahasiswa sebagai anggota kelompok yang mengikuti unit kegiatan mahasiswa yang mengikuti UKM Futsal Puteri UPI sangat penting untuk dianalisis secara mendalam karena pada prinsipnya mahasiswa tersebut dapat menampilkan perilaku sosial yang baik terhadap lingkungan sosialnya.

Hasil dari penelitian dari keseluruhan perilaku sosial atlet puteri cabang olahraga futsal yang terjadi pada mahasiswa puteri yang mengikuti UKM futsal puteri UPI Bandung memiliki skor faktual sebesar 5311 dan skor ideal 6500 sehingga memiliki persentase nilai 
sebesar $65 \%$, yaitu baik. Adapun perilaku sosial atlet puteri cabang olahraga futsal yang terjadi pada mahasiswa puteri yang mengikuti UKM futsal puteri UPI Bandung dominan memiliki perilaku sosial dalam penyesuaian diri terhadap diri sendiri dengan skor faktual sebesar 887 dan skor ideal 1040 sehingga penyesuaian diri terhadap diri sendiri memiliki persentase nilai sebesar $85.2 \%$, yaitu sangat baik. Sedangkan dari butir-butir pernyataan tiap sub komponen yang paling menonjol adalah adanya keinginan yang besar, sedangkan kemampuan yang dimiliki kurang dengan skor faktual 483 dan skor ideal 520 sehingga persentase yang di dapat adalah 92.2\%, yaitu sangat baik.

Perilaku sosial dapat diartikan sebagai segala sesuatu yang dilakukan atau dialami seseorang dalam konteks sosial. Sedangkan pada konteks olahraga yaitu seperangkat gerakan-gerakan yang dilakukan oleh seorang individu sebagai hasil interaksi individu dengan individu yang lain dan berlangsung dalam waktu tertentu. Perilaku sosial individu akan ditampilkan apabila berinteraksi dengan orang lain. Dalam respons tertentu yang sifatnya cenderung konsisten dan stabil, sehingga dapat ditampilkan dalam situasi sosial yang berbeda-beda. Pernyataan tersebut didukung oleh penelitian Kusumawati (2010), dalam penelitiannya kegiatan ekstrakurikuler olahraga memberikan dampak lebih besar terhadap perilaku sosial terhadap siswa dibandingkan kegiatan ekstrakurikuler non olahraga, karena dengan mengikuti kegiatan ekstrakurikuler olahraga secara tidak sadar siswa akan dapat merubah perilaku sosial ke arah yang lebih positif dengan sendirinya yaitu melalui permainan dan olahraga. Dalam hal ini Saifuddin (1988:30) menjelaskan mengenai pembentukan perilaku atau sikap adalah:

Diantara berbagai faktor yang mempengaruhi pembentukan perilaku adalah pengalaman pribadi, kebudayaan, orang lain yang dianggap penting, media massa, institusi atau lembaga pendidikan dan lembaga agama, serta faktor emosi dalam diri individu.

Sedangkan menurut Hosland, Janis, dan Kelley 1953 (1982:26) menjelaskan bahwa: “Proses dari perubahan perilaku adalah serupa dengan proses belajar. Dalam mempelajari 
sikap yang baru, ada tiga variabel penting yang menunjang proses belajar tersebut adalah: perhatian, pengertian, dan penerimaan".

Pendapat tersebut diungkapkan bahwa perilaku itu dibentuk oleh dua faktor, yaitu faktor internal dan faktor eksternal. Faktor internal yang dimaksud adalah pengalaman pribadi dan emosi. Sedangkan yang termasuk faktor eksternal adalah kebudayaan, orang lain yang dianggap penting, media massa, institusi atau lembaga pendidikan dan lembaga agama.

Berdasarkan uraian di atas, maka olahraga futsal merupakan salah satu bentuk olahraga yang dapat mengembangkan keterampilan sosial seseorang. Hal ini dikarenakan olahraga beregu akan membentuk sebuah situasi sosial yang dapat memberikan kesempatan kepada individu untuk berinteraksi dengan orang lain. Salah satu bagian dari keterampilan sosial adalah perilaku sosial. Seperti yang diungkapkan dalam penelitian Nopembri (2008), dalam penelitiannya mengimplikasikan bahwa olahraga futsal harus dapat dikembangkan menjadi olahraga masyarakat yang disinergikan dengan olahraga pendidikan dan prestasi serta model pengembangn keterampilan sosial. Melalui olahraga futsal dapat diaplikasikan dalam pendidikan dengan merancang pembelajaran yang dapat menciptakan interaksi sosial yang positif untuk merangsang timbulnya berbagai perilaku positif yang mengarah pada penegembangan keterampilan.

\section{KESIMPULAN DAN REKOMENDASI}

Berdasarkan hasil pengolahan dan analisis data yang telah diuraikan pada bab IV, dapat dijabarkan kesimpulan dari hasil penelitian yang dilakukan adalah gambaran perilaku sosial atlet puteri cabang olahraga futsal pada mahasiswa yang mengikuti UKM futsal puteri UPI Bandung memiliki perilaku sosial yang baik.

Berdasarkan hasil penelitian ini, penulis memberikan rekomendasi yang dapat dipertimbangkan sebagai berikut: 
1. Bagi pihak Universitas diharapkan lebih bisa memberikan perhatian terhadap minat dan bakat mahasiswa dalam pengembangan perilaku sosial yang dibentuk melalui unit kegiatan mahasiswa.

2. Bagi para pelatih atau pembina cabang olahraga khususnya olahraga futsal, hendaknya mampu memahami dan menangani mahasiswa dalam membuat program yang menarik bagi perkembangan perilaku sosial mahasiswa sebagai bekal mereka untuk menjadi manusia yang seutuhnya yang berprilaku positif dan baik.

3. Bagi para mahasiswa pada umumnya, dan khususnya mahasiswa yang mengikuti UKM futsal penelitian ini diharapkan bisa bermanfaat dalam perkembangan perilaku sosial mereka di lingkungan masyarakat.

4. Berkaitan dengan penelitian ini yang penulis lakukan, sebaiknya diadakan penelitian lebih lanjut dengan jumlah sampel yang lebih banyak dan representative serta didasari oleh kajian teori yang lebih mendalam, sehingga hasilnya akan memberikan gambaran lebih nyata terhadap perilaku sosial atlet puteri cabang olahraga futsal pada mahasiswa yang mengikuti UKM futsal puteri UPI Bandung. 


\section{DAFTAR PUSTAKA}

Coakley, J. (2001). Sport in Society: Issues and Controversies. New york: McGraw-Hill.

Giriwijoya, dkk. (2012). Ilmu Faal Olahraga. Bandung: PT. Remaja Rosdakarya.

Harsono. (1988). Coaching dan Aspek-aspek Psikologis dalam Coaching. Jakarta: CV. Tembak Kusuma.

Husdarta. (2010). Psikologi Olahraga. Bandung: Alfabeta.

Kusumawati, M. (2011). Dampak Kegiatan Ekstrakurikuler Olahraga Terhadap Perilaku Sosial. Tesis Pascasarjana Universitas Pendidikan Indonesia.

Lutan, R. (2001). Olahraga dan Etika. Jakarta: CV. Berdua Satutujuan, Wihani Group.

Mar'at. (1982). Sikap Manusia Perubahan Serta Pengukurannya. Jakarta: Ghalia Indonesia.

Nopembri, S. (2008). Model Pengembangan Keterampilan Sosial Melalui Olahraga Futsal (Studi Interaksi Sosial pada Masyarakat yang Berprestasi dalam Olahraga Futsal). Tesis Pascasarjana Universitas Pendidikan Indonesia.

Saefuddin, A. (1988). Sikap Manusia, Teori dan Pengukurannya. Yogyakarta: Liberty.

Willis, S. S. (2011). Psikologi Pendidikan. Bandung: Alfabeta.

(2007). Menuju Keberhasilan Studi Mahasiswa. Bandung: UPI. 